\title{
The Relationship Between Mathematical Problem-Solving Ability, Mathematical Connection Ability, and Ability to Read the Qur'an
}

\author{
Fatrima Santri Syafri ${ }^{1, *}$, Dodi Isran ${ }^{2}$, Nurhikma $^{1}$ \\ ${ }^{1}$ Lecturer in IAIN Bengkulu, Indonesia \\ ${ }^{2}$ Lecturer in STIESNU Bengkulu, Indonesia \\ *Corresponding author. Email: fatrimassyafri@iainbengkulu.ac.id
}

\begin{abstract}
Problem solving skills and mathematical connection skills are mathematical abilities that must be possessed by students. In addition this ability can also hone the ability of students to solve everyday problems. Therefore, as a prospective teacher, students must have reliable mathematical abilities. This study aims to determine the relationship between mathematical problem solving ability and mathematical connection ability and the ability to read the Qur'an . In the mathematics tadris study program of IAIN (Institut Agama Islam Negeri) Bengkulu, students are prepared to have these mathematical abilities but are also required to have the ability to read the Qur'an. This research was a survey research with a population of 110 people. The results of data analysis show that the latent variable of the ability to read the Qur'an $(\mathrm{X} 1, \mathrm{X} 2, \mathrm{X} 3)$ is only at X1 (result $>0.05$ and $t$ value $>1.96$ ), with the reliability of the three is more than 0.7 The variable latent mathematical connection capability $(\mathrm{X} 4, \mathrm{X} 5, \mathrm{X} 6)$ only at X4 (>0.05 and t value $>1.96)$, with the reliability of the three is more than 0.7 . The latent variable is problem solving ability $(\mathrm{X} 7, \mathrm{X} 8, \mathrm{X} 9$, $\mathrm{X} 10$ ) only at X7 (> 0.05 and $t$ value $>1.96$ ), with the reliability of the three was more than 0.81 . Therefore, it can be concluded that there is a positive direct influence between the ability to solve mathematical problems, the ability to connect mathematics, and the ability to read the Qur'an,
\end{abstract}

Keywords: Mathematical problem-solving ability, mathematical connection, ability to read the Qur'an.

\section{INTRODUCTION}

Mathematics is a compulsory subject for elementary and middle school students. Widada [1] stated that "Mathematics was a compulsory subject for elementary and middle school students". Based on this statement, it concluded that Mathematics is a subject that must be studied by elementary and middle school students. Unfortunately, The students still think that math is a difficult subject to understand. It seems for the ability to solve math problems is weak. So this problem affects students' motivation to learn mathematics and students' achievement [2].

On the other hand, mathematical problem-solving abilities can be done by students if the students understand the concepts of mathematics. Following the opinion of Widada and Herawati [3] stated that someone is said to have no conceptual understanding if in solving problems they do not use the concepts that have been learned without logical reasons, or fail in their implementation. Misconceptions and misrepresentations of the idea related to solving a given problem. It concluded that solving mathematical problems is an attempt to find a solution.

Mathematics learning is a learning process that teaches students to solve problems both directly related to mathematics and outside the context of mathematics. According to Branca [4] the essence of mathematics learning is problem solving ability. According to Ruseffendi [5] problem solving is very important in mathematics because in everyday life, they need mathematics. In line with this, Leo Adhar [6] said that problem solving ability is an ability 
that students must have to be trained to face various problems in mathematics and other subjects.

In learning mathematics, a student must have good problem solving skills [1]. Polya [7] states that problem solving is a very high intellectual activity, meaning that problem solving is a cognitive activity to find alternative solutions using background knowledge. According to Bradshaw et al. [8], problem solving is a skill that can formulate unique ways to solve a problem. Based on the definitions of the experts above, it is concluded that the ability to solve mathematical problems is a skill to find alternative problem solving.

According to The National Council of Teachers of Mathematics, NCTM [9] there are four standard indicators of problem solving: 1) Building new mathematical knowledge through problem solving. 2) Solve problems that arise in mathematics and other subjects. 3) Implement and adapt the right strategy to solve problems. 4) Observe and develop the process of solving mathematical problems. According to Zarkasyi [10] problem solving ability has several indicators. 1) identify the elements that are known, asked for, and the adequacy needed, 2). Formulating mathematical problems or compiling mathematical models, 3) Implementing strategies in solving problems, 4) Explaining or interpreting the results of problem solving.

According to NCTM [9] the standard process of learning mathematics is: first, solving math problems; second, mathematical reasoning and proof; third, mathematical communication; fourth, mathematical relations; and fifth, mathematical representation. Mathematics learning process standards include mathematical connections which are important things that must be owned by students. NCTM [9] has two general types of mathematical connections, modeling connections, and mathematical connections. Modeling relationship is the relationship between problem situations that arise in the real world or some other subjects with their mathematical representations. Furthermore, the mathematical relationship is the relationship between two equivalent representations between the completion process of each representation.
The mathematical connection ability is an ability that students must have in order to have a critical attitude so that students are able to solve problems in mathematics. in connecting mathematics both with other materials and in daily life students should also have the ability to solve problems. Mathematical connection ability is the ability to provide information with a critical attitude in evaluating something and has metacognitive awareness and problem solving skills [11]. Mathematical connections are activities that include: (1) looking for relationships between various representations of concepts and procedures, (2) understanding relationships between mathematical topics, (3) using mathematics in other fields of study or everyday life. (4) ) looking for connections or other procedures in an equivalent representation, and (5) using connections between mathematical topics and other topics [12].

Mathematical connection is an activity in mathematics that connects the concepts and procedures of mathematical topics with several other fields of study that can be applied to everyday life. The relationship between everyday life and the topics to be studied will increase understanding in learning mathematics. Activities that can support the improvement of mathematical connection skills are being able to connect relationships between mathematical topics, and looking for linkages between external contexts outside mathematics and mathematics.

Based on the expert opinion above, it can be concluded that the mathematical connection ability is the ability of students to test the relationship between mathematical concepts and procedures and use them in other fields of study or everyday life. NCTM [9] states that there are three indicators of mathematical connection ability, namely: 1) Recognizing and using relationships between mathematical ideas. 2) Understand how mathematical ideas are related and interrelated to form a complete system. 3) Knowing and applying mathematics in other fields. Mathematical problem solving abilities and mathematical connection abilities of students in the Mathematics Education Study Program as prospective mathematics teachers must have different levels of ability from students in other study programs. However, 
in a Islamic Institution, prospective mathematics teachers are also expected to have good math skills and good ability to read the Qur'an compared to other public universities.

Furthermore, the word of ability in the Big Indonesian Dictionary [13] comes from the word "able" which gets prefixes and suffixes which mean the ability, ability, and strength to do something. Reading is a process where information from the text and knowledge possessed by the reader has a big role in shaping meaning. Syukur [14] said AlQur'an is the name for the word of Allah that was revealed to the Prophet Muhammad which is poured into the Mushaf to be used as a guide for human life when reading will be rewarded. The ability to read the Qur'an is the skill to read the Qur'an correctly. So the ability to read the Al-Qur'an that is meant by the researcher is the student's ability to pronounce what is written in the Qur'an correctly according to his makraj. Indicators in reading the Qur'an for this research are: 1). fluent in reading the Qur'an, fluent which is the basic word of fluency according to the KBBI [13] which means uninterrupted, choked up, fluent. 2). The accuracy of reading the Qur'an is in accordance with the principle of tajwid, the science of reciting the Qur'an is a choice, but reading the Qur'an according to the law of tajwid is fardhu 'ain / obligation. 3). The suitability of reading with pronounciation (makharijul) letters according to tombak alam [15] mahkrijul letters is to read letters according to the place where the letters come out such as in the throat, middle tongue, between two lips and others. Broadly speaking, makhrijul letters are divided into 5 types, throat cavity, halq (throat), mouth (tongue), syafataani (two lips) and khoisyum (nose bridge).

According to Aquami [16] in his research, he states that there is an interplay between the ability to read the Qur'an and Arabic writing skills in the subject of the Qur'an . Students who have good Al-Quran reading skills then have good Arabic writing skills as well. Furthermore, research conducted by Hasri and Nur Rahma [17] states that students' ability to read and write the Qur'an in terms of knowing / recognizing Arabic letters, being able to read the Qur'an correctly has a significant correlation with math skills. Students who have good math skills have the ability to read and write the Al-Quran well.

The results of Hasri's research [17] show that (1) the students' ability to read and write the Qur'an shows an average score of 87,1096 with a frequency of 53 people in the very high category $(72.5 \%)$. This means that students' ability to read and write the Qur'an in terms of knowing / recognizing Arabic letters, being able to read the Qur'an correctly and being able to write several verses of the Qur'an is already very good; (2) The level of student ability shows an average score of 86.2877 with a frequency of 50 people being in the very high category $(68.5 \%)$. This means that students' ability in terms of reasoning, inductive reasoning, understanding, problem solving, connections, communication, analytical thinking and creative thinking and analogy is very good; and (3) the students' ability to read and write the Qur'an has a significant correlation with their mathematical abilities. The inferential analysis results show that the correlation coefficient $\mathrm{r}=0.608$ and the determination coefficient $r^{2}=0.3697$ or $36.97 \%$ that interpreted as moderate.

Previous research on mathematical abilities in general has seen the relationship with the ability to read the Qur'an but did not explain in detail about these mathematical abilities. Based on theoretical studies and the results of previous research, this paper will look at the relationship between mathematical problem-solving abilities, mathematical connection skills and the ability to read $\mathrm{Al}$ Qur'an students of the Mathematics study program at IAIN Bengkulu.

\section{RESEARCH METHODS}

This study used a survey research method. This research aims to see the relationship between mathematical problemsolving abilities, mathematical connection skills, and the ability to recite the Qur'an. In conducting the study, the researcher used all students of the Mathematics study program IAIN Bengkulu as Population. Furthermore, the paper designed is an ex post facto correlation study. Ex-post facto research is a study in which the independent variables occurred when the researcher started with the observation of the dependent variable [18].

There are 110 people taken randomly as a sample of research. There are three 
variables, first the ability to solve mathematical problems, second the ability to connect mathematically and third the ability to read the Qur'an. The research instrument used was the Qur'an reciting test, a test of mathematical problem-solving skills and mathematical connection skills. Data were analyzed using structural modeling with the help of LISREL 9.2 software to test structural models directly or indirectly from these latent variables.

Retrieval of data in this study was to provide several mathematical questions consisting of questions to measure mathematical problem-solving abilities and mathematical connection abilities. Furthermore, the researcher collected the values of the ability to read the Qur'an, which had been assessed by the team of the Center for Islamic Studies and Culture (PUSBAKIK) IAIN Bengkulu. Then, the researcher analyzed the score of mathematical problemsolving abilities and the ability of mathematical connections as well as their correlation to the ability to recite Al-Qur'an.

\section{RESULTS AND DISCUSSION}

The data from this study were the ability to solve mathematical problems $(=\mathrm{PM})$, the ability to connect mathematically $(=\mathrm{KM})$ and the ability to read the Qur'an (= MA). The latent variable indicator of the ability to read Al-Qur'an is the fluency of reading Al-Qur'an (X1), the accuracy of reading the Al-Qur'an according to the principles of tajwid (X2), and the suitability of reading with pronounciation (makharijul) letters (X3). latent variable indicators of the ability of mathematical connections include recognizing and using relationships between mathematical ideas (X4), understanding how mathematical ideas are related and interrelated so that they form a complete system (X5), and applying mathematics in other fields (X6). Latent variable indicators of problem solving abilities include building new mathematical knowledge through problem solving (X7), solving problems that arise in mathematics and in other fields (X8), implementing and adjusting various strategies suitable for solving problems (X9), observing and developing process of solving mathematical problems (X10).

Data were analyzed using Lisrel 9.2. the results of data analysis are presented in Figure 1 (Basic Model Standardized Solution).

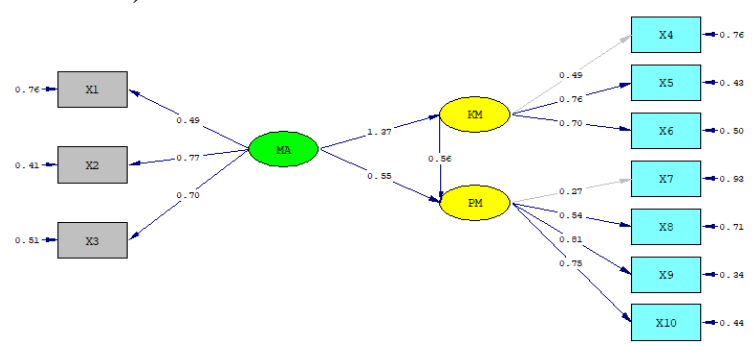

Figure 1. Basic Model Standardized Solution

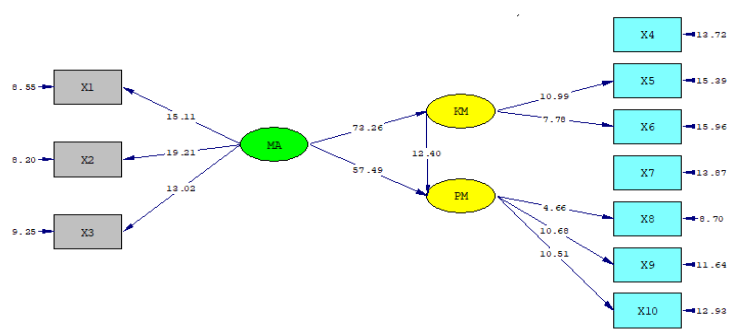

Figure 2. Basic model T-values

Based on the path diagram (Figures 1 and 2), it can be concluded in the table to determine the validity of each indicator variable and the reliability of each latent variable. Also some other variables can be presented in table 1 , table 2 and table 3.

Table 1. Validity and reliability of the ability to read Al quran

\begin{tabular}{|c|c|c|c|c|c|c|}
\hline \multirow{2}{*}{ Indicator } & \multirow{2}{*}{$\begin{array}{c}\text { SLF } \geq \\
0.50\end{array}$} & \multirow{2}{*}{$\begin{array}{c}\text { Standar } \\
\text { Error }\end{array}$} & \multirow{2}{*}{ T-Value } & \multirow{2}{*}{ Declation } & \multicolumn{2}{|c|}{ Reliability } \\
\hline & & & & & $\mathrm{CR} \geq 0.7$ & $\mathrm{VE} \geq 0.5$ \\
\hline $\mathrm{X} 1$ & 0.49 & 0.76 & 15.11 & deficient & \multirow{3}{*}{0.77} & \multirow{3}{*}{0.70} \\
\hline $\mathrm{X} 2$ & 0.77 & 0.41 & 19.21 & good & & \\
\hline X3 & 0.70 & 0.51 & 13.02 & good & & \\
\hline
\end{tabular}

Table 2. Latent variables of mathematical connection ability

\begin{tabular}{|c|c|c|c|c|c|c|}
\hline \multirow{2}{*}{ Indicator } & \multirow{2}{*}{$\begin{array}{c}\text { SLF } \geq \\
0.50\end{array}$} & \multirow{2}{*}{$\begin{array}{c}\text { Standar } \\
\text { Error }\end{array}$} & \multirow{2}{*}{ T-Value } & \multirow{2}{*}{ Declation } & \multicolumn{2}{|c|}{ Reliability } \\
\hline & & & & & $\mathrm{CR} \geq 0,7$ & $\mathrm{VE} \geq 0,5$ \\
\hline $\mathrm{X} 4$ & 0.49 & 0.76 & - & deficient & 0.76 & 0.70 \\
\hline
\end{tabular}




\begin{tabular}{|c|c|c|c|c|c|c|}
\hline X5 & 0.76 & 0.43 & 10.99 & good & & \\
\hline X6 & 0.70 & 0.50 & 7,78 & good & & \\
\hline
\end{tabular}

From table 1, it can be seen that the latent variable of the ability to read al-qur'an $(\mathrm{X} 1, \mathrm{X} 2, \mathrm{X} 3)$ is only at $\mathrm{X} 1(>0.05$ and $\mathrm{t}$ value $>1.96)$ the validity is not good but the reliability of the three is more than 0.7 .
From the table 2, it can be seen that the latent variables of mathematical connection ability $(\mathrm{X} 4, \mathrm{X} 5, \mathrm{X} 6)$ are only at X4 (> 0.05 and $t$ value $>1.96)$, the validity is not good, but the reliability of the three is more than 0.7 .

Table 3. Validity and Reliability of Problem Solving Ability

\begin{tabular}{|c|c|c|c|c|c|c|}
\hline \multirow{2}{*}{ Indicator } & \multirow{2}{*}{$\begin{array}{c}\text { SLF } \geq \\
0.50\end{array}$} & \multirow{2}{*}{$\begin{array}{c}\text { Standar } \\
\text { Error }\end{array}$} & \multirow{2}{*}{ T-Value } & \multirow{2}{*}{ Declation } & \multicolumn{2}{|c|}{ Reliability } \\
\hline & & & & & $\mathrm{CR} \geq 0.7$ & $\mathrm{VE} \geq 0.5$ \\
\hline $\mathrm{X7}$ & 0.27 & 0.93 & - & deficient & \multirow{3}{*}{0.81} & \multirow{3}{*}{0.54} \\
\hline $\mathrm{X} 8$ & 0.54 & 0.71 & 4.66 & good & & \\
\hline $\mathrm{X} 9$ & 0.81 & 0.34 & 10.68 & good & & \\
\hline $\mathrm{X} 10$ & 0.75 & 0.44 & 10.51 & good & & \\
\hline
\end{tabular}

From the table above, it can be seen that the latent variable of problem solving ability (X7, X8, X9, X10) is only at X7 (> 0.05 and the value of $t>1.96)$ the validity is not good but the reliability of the three is more than 0.81 . Therefore, based on figures 1 and 2 can answer the hypothesis:

Hypothesis 1: There is a positive direct effect of the ability to read the Qur'an on problem solving abilities.

Hypothesis 2: There is a positive influence on the ability to read the Qur'an through the ability of mathematical connections to problem solving abilities.

Hypothesis 3: There is a positive influence on mathematical connection ability on problem solving ability.

Based on the data analysis, it was found that the reliability value of the mathematical connection ability was $\mathrm{CR} \geq$ 0.7 (0.76), $\quad \mathrm{VE} \geq 0.5(0.7)$ and the mathematical problem solving ability was $\mathrm{CR} \geq 0.7$ (0.81), $\mathrm{VE} \geq 0.5$ (0.54) so it can be concluded that there is a positive direct influence between the ability to read the Qur'an the ability to solve math problems, and the ability to connect mathematics. And it can be concluded that there is a positive direct influence on the ability to read the Qur'an, there is a positive influence on the ability to solve mathematical problems, there is a positive influence on the ability of mathematical connections. The results of significant research on the research of Hasri and Nur Rahma [17] show that the ability to read and write al-quran students in terms of knowing / recognizing Arabic letters, being able to read al-quran correctly has a significant correlation to mathematical skills. Students who have good mathematical skills have the ability to read and write the Al Quran as well.

Mathematics itself has a very close relationship with the spiritual traditions of Muslims, is familiar with the Qur'an, and of course mathematics can also be used as a "path" towards achieving happiness-benefits both in this world and the hereafter. In the Qur'an, there are many verses that explain mathematical concepts, including sets, sequences, whole numbers, whole numbers, fractions, and circles. This statement suggests that there is a close relationship between the Quran and mathematics. Understanding in reading the Al-Qur'an should also be able to understand the contents in it, because in the Al-Qur'an it describes several concepts in mathematics.

\section{CONCLUSIONS}

Based on the results, it is concluded that there is a positive influence on the ability to recite or read the Qur'an and the ability to solve mathematical problems, as well as a positive impact on the skills of mathematical connections. However, further research is needed to determine the relationship between other mathematical skills toward the ability to recite and write Al-Quran.

\section{REFERENCES}

[1] W. Widada, D. Herawaty, A. F. D. Anggoro, A. Yudha, and M. K. Hayati, 
"Ethnomathematics and outdoor learning to improve problem solving ability," 2019.

[2] W. Widada, "Proses pencapaian konsep matematika dengan memanfaatkan media pembelajaran kontekstual," $J$. Penelit. Pendidik. Mat. dan Sains, vol. 22, no. 1, pp. 31-44, 2015.

[3] W. Widada and D. Herawaty, "Realistic mathematics learning based on bengkulu ethnomatematics to increase cognitive level," in Bengkulu International conference on science and education, 2017, pp. 14-15.

[4] N. A. Branca, "Problem solving as a goal, process, and basic skill," Probl. solving Sch. Math., vol. 1, pp. 3-8, 1980 .

[5] E. T. Ruseffendi, "Pengantar kepada membantu guru mengembangkan kompetensinya dalam pengajaran matematika untuk meningkatkan CBSA," Bandung: tarsito, 2006.

[6] L. A. Effendi, "Pembelajaran matematika dengan metode penemuan terbimbing untuk meningkatkan kemampuan representasi dan pemecahan masalah matematis siswa SMP," J. Penelit. Pendidik., vol. 13, no. 2, pp. 1-10, 2012.

[7] L. Lestari and D. Sofyan, "Perbandingan Kemampuan Pemecahan Masalah Siswa Dalam Matematika Antara Yang Mendapat Pembelajaran Matematika Realistik (Pmr) Dengan Pembelajaran Konvensional," Mosharafa J. Pendidik. Mat., vol. 3, no. 2, pp. 95-108, 2014, Accessed: Jan. 18, 2021. [Online]. https://journal.institutpendidikan.ac.id/i ndex.php/mosharafa/article/view/mv3n $2 \_4$.

[8] Z. Bradshaw and A. Hazell, "Developing problem-solving skills in mathematics: a lesson study," Int. J. Lesson Learn. Stud., 2017.

[9] NCTM, "Standards for School Mathematics. United States of America: The National Council of Teachers of Mathematics." Inc, 2000.

[10] Z. Wahyudin, Penelitian Pendidikan Matematika. Bandung: PT Refika Aditama, 2015.

[11] D. Rohendi and J. Dulpaja, "Connected Mathematics Project (CMP) model based on presentation media to the mathematical connection ability of junior high school student," J. Educ. Pract., vol. 4, no. 4, 2013.

[12] U. Sumarmo, "Berpikir Dan Disposisi Matematik: Apa, Mengapa, dan bagaimana dikembangkan pada peserta didik," Bandung FPMIPA UPI, 2010.

[13] K. B. B. Indonesia, "Tim Penyusun Kamus Pusat Bahasa," Balai Pustaka. Jakarta, 2001.

[14] H. M. A. Syukur, Pengantar Studi Islam. Pustaka Nuun, 2010.

[15] T. Alam, "Ilmu Tajwid," Jakarta: Amzah, 2009.

[16] A. Aquami, "Korelasi antara Kemampuan Membaca Al-Qur'an dengan Keterampilan Menulis Huruf Arab pada Mata Pelajaran Al-Qur'an Hadits di Madrasah Ibtidaiyah Quraniah 8 Palembang," JIP J. Ilm. PGMI, vol. 3, no. 1, pp. 77-88, 2017, doi: 10.19109/jip.v3i1.1379.

[17] H. Hasri and N. Rahmah, "Kemampuan Baca Tulis Al-Quran dan Korelasinya terhadap Kemampuan Matematika Mahasiswa Prodi Tadris Matematika IAIN Palopo," Al-Khwarizmi J. Pendidik. Mat. dan Ilmu Pengetah. Alam, vol. 4, no. 2, pp. 163-172, 2016.

[18] Sukardi, Metodologi penelitian pendidikan kompetensi dan praktiknya. Jakarta: umi Aksara., 2014. 